\title{
Authentication of Sumateran Wild Boar (Sus scrofa vittatus) Meat Contamination by Polymerase Chain Reaction Restriction Fragment Length Polymorphism (PCR-RFLP) Technique of Cytochrome b Gene
}

\author{
M. W. Adiningsih ${ }^{a}, b, *$, R. D. Soejoedonoc, T. Purnawarman ${ }^{c}$, H. Latif ${ }^{c}$, O. N. Poetri ${ }^{c}$, \& D. D. Putri ${ }^{d}$ \\ ${ }^{a}$ Veterinary Public Health, Graduate School, Bogor Agricultural University \\ bIndonesia Agricultural Quarantine Agency, Ministry of Agriculture \\ Jalan Harsono RM. 3 Ragunan Jakarta Selatan 12550, Indonesia \\ 'Department of Animal Diseases and Veterinary Public Health, Faculty of Veterinary Medicine, \\ Bogor Agricultural University \\ Kampus IPB Dramaga, Bogor 16680, Indonesia \\ dDepartment of Animal Husbandry, Faculty of Animal Husbandry, State Polytechnic of Lampung \\ Jalan Soekarno-Hatta No.10, Bandar Lampung, Provinsi Lampung, Indonesia \\ *Email of corresponding author: melani_skhmerak@yahoo.co.id \\ (Received 22-03-2018; Reviewed 06-06-2018; Accepted 26-07-2018)
}

\begin{abstract}
High population of Sumateran wild boar causes the increasing number of hunting and overflowing of wild boar meat availability in the market at a very low price. This condition leads to the falsification of meat. This study was aimed to characterize and differentiate Sumateran wild boar meat (Sus scrofa vittatus) and beef (Bos taurus) since Sumateran wild boar meat is often falsified as a beef in Indonesian traditional market. The domesticated pork meat (Sus scrofa domestica) was also investigated to compare Sumateran wild boar meat and domestic pork. Samples used in this study were DNA (deoxyribonucleic acid) from pork (Sus scrofa domestica), Sumateran wild boar meat (Sus scrofa vittatus), and beef (Bos taurus). Beef and pork were obtained from traditional markets in Bogor city whereas Sumateran wild boar meat was obtained from Way Kanan Regency, Lampung Province. Herein, we performed a thorough investigation on Sumateran wild boar meat (Sus scrofa vittatus) and beef (Bos taurus) using polymerase chain reaction-restriction fragment length polymorphism (PCR-RFLP) method. This study utilized cytochrome $b$ primer from mitochondria DNA with the size target amplification of $359 \mathrm{bp}$. This study utilized the restriction endonuclease enzymes, i.e. $A l u \mathbf{I}, B s a \mathbf{I I}, H i n d \mathbf{I I I}, R s a \mathbf{I}, H a e I I I$, and $T a q^{\alpha} \mathbf{I}$, in order to digest the amplification products from cytochrome $b$ gene. The results showed that $H a e I I I$ is the merely specific enzyme to discriminate wild boar meat, domestic pork, and beef since HaeIII was able to digest these three meats in different locations of $c y t b$ gene. However, $A l u \mathbf{I}, B s a \mathbf{I} \mathbf{I}, H i n d \mathbf{I I I}, R s a \mathbf{I}$, and Taq ${ }^{\alpha} \mathbf{I}$ enzymes were not specific enough to differentiate wild boar meat and domestic pork. In conclusion, among six tested enzymes, the use of PCR-RFLP analysis of the $c y t b$ gene followed by digestion using HaeIII restriction enzyme provides a simple, relatively quick, and accurate identification of Sumateran wild boar species.
\end{abstract}

Keywords: HaeIII, meat falsification, PCR-RFLP, Sumateran wild boar meat

\section{INTRODUCTION}

Sumateran wild boars have been superabundant in Sumateran forest (Ickes 2001). In Indonesia, this wildlife condition has led to the exploitation of this wild boar for commercial purpose (Luskin et al., 2013). The high number of Sumateran wild boars population increases wild boar hunting resulting in an abundant availability of wild boar meat in the food market with extremely cheap price. The macroscopic similarity of wild boar meat and beef has prompted the local people to abuse this situation by selling wild boar meat in traditional market as beef. This condition is supported by the large demand and high price of beef. Trading is not only happened in Sumatra but also in Java Province. The situation does not only occur in Sumatra but also expanded to Java increasingly year by year. Based on annual record from Cilegon Class II Quarantine Office in 2014, there were nine smuggling cases or a total of $21.556 \mathrm{~kg}$ of wild boar meat smuggling effort that were prevented by Cilegon Quarantine officers (Bkpcilegon, 2015). The number of food safety concerns related to smuggling of wild boar or counterfeiting beef with wild boar is a very detrimental condition for consumers, especially consumers in traditional markets since both types of these meats are difficult to distinguish macroscopically. Furthermore, counterfeiting beef to wild boar meat is a big problem in Indonesia because wild boar meat is a non halal food for Indonesian people who mostly are moslem. 
The checking of genuineness or validity of food products is an important effort to protect people from consuming unhealthy food and to indicate whether the food is halal or not. Studies of meat detection should be continuously developed as an effort to protect consumers. Based on the equipment, methodology, and the techniques used, as well as the cost and procedure of sample preparation, different methods have been proposed for identification of meat species, all based on either protein or DNA analysis (Alikord et al., 2017). Genetic method is the most specific and sensitive method to check food ingredients authenticity by detecting the presence of genetic material or deoxyribonucleic acid (DNA). It results from the specific character of the structure of DNA particles and the possibility of using the information included in them (Karabanasavar et al., 2011; Spychaj et al., 2016). The most frequent loci used for species identification in phylogenetic and biodiversity studies are mitochondrial cytochrome b (cyt $b$ ) (Oceja et al., 2017).

There are some various methods used for identification of species origin of raw meat include sensory analysis, histological differentiation of the hair that may possibly exist in the meat, electrophoresis and immune sera diffusion in agar gel, properties of tissue fat, level of glycogen in muscle tissue, anatomical differences, electrophoresis, and DNA hybridization. It has been argued, however, that these methods have some problems that limit their uses such as specificity, difficulty, complexity, and high cost. They may also be time consuming, inadequate to discriminate between species which are in close relation or not suitable for routine use (Haider et al., 2012)

Murugaiah et al. (2009) in their study said that in recent years, many investigators applied various typing methods to identify species in meat, including PCR amplification, PCR-based amplified fragment length polymorphism (AFLP), random amplification of polymorphic DNA (RAPD), quantitative competitive (QC) PCR, multiplex PCR, nested primer PCR, microsatellite, and real-time PCR. In addition to the above techniques, a PCR-RFLP analysis has been widely developed for the typing and the differentiation of animal and fish species.

Genetic method is the most specific and sensitive tool for analyzing the authenticity of food ingredients in a molecular level by means of detecting the presence of genetic material or deoxyribonucleic acid (DNA). One of the various methods could be used to detect genetic material is polymerase chain reaction (PCR). Specifically, one of such method frequently used in food industry to observe animal derived product fabrication is PCR restriction fragment length polymorphism (RFLP). PCRRFLP is based on the comparison of the bands profile generated after certain enzymes digest the DNA target. PCR-RFLP is appropriate for meat testing due to its ability in exploiting sequence variation in designated DNA region that allows species differentiation even from closely related species through DNA fragment restrictions selected by suitable restriction enzyme (Pascoal et al., 2004; Farag et al., 2015). PCR-RFLP is advantageous since it is simple, cheaper, and easier to be adjusted for routine big-scale studies such as surveillance program (Fajardo et al., 2007).

The species identification using PCR-RFLP of mitochondria cyt $b$ segment has been reported by Lenstra et al. (2001) in cheese samples of water buffalo, cattle, goat, and sheep as well as by Mutalib et al. (2012) in meat samples of pork and wild boar meat. Electrophoresis specific DNA fragment of cyt $\beta$ gene was presented by Minarovic et al. (2010) and they successfully identified species using PCR-RFLP with the same primer for all species (i.e. Mustela vision (American mink), Mustela putorius furo (Ferret), Sus scrofa domestica (Pig), and Oryctolagus cuniculus (Rabbit)) which were designed by Kocher et al (1989). PCR products lengths did not different for all species, i.e., $359 \mathrm{bp}$ (Irine et al., 2011). The novelty of this study was to distinguish between Sumateran wild boar meat, pork, and beef. This research aims to understand the authentication of Sumateran wild boar (Sus scrofa vittatus) contamination through PCR method by cyt $b$ primer and the restriction enzymes.

\section{MATERIALS AND METHODS}

\section{Sample Preparation}

In this study we used non template control (NTC) for negative control. Fresh pork (Sus scrofa domestica) $(n=7)$ and frozen beef (Bos taurus) $(n=7)$ were obtained from wet market in Bogor city. Fresh Sumateran wild boar meat (Sus scrofa vittatus) $(\mathrm{n}=7)$ was obtained from Way Kanan Regency, Lampung Province. The samples used in this study were collected from the longest lumbar muscle ( $m$. longissimus lumborum), the material was placed in sterile tubes and stored at $-80^{\circ} \mathrm{C}$ until use.

\section{Extraction of Total DNA}

The DNA of fresh raw beef, pork, and wild boar meat were extracted using DNA extraction kit (Qiamp® DNA Mini Kit, Qiagen, Germany), according to the protocol from manufacturer. A total of $25 \mathrm{mg}$ meat from each sample was minced in a $1.5 \mathrm{~mL}$ sterile microcentrifuge tube and added with $180 \mu \mathrm{L}$ ATL buffer (Tissue lysis buffer). As much as $20 \mu \mathrm{L}$ of proteinase $\mathrm{K}$ was added and the mixture was vortexed and then incubated in $56^{\circ} \mathrm{C}$ for $16 \mathrm{~s}$ until the samples had been lysed completely (1-3 h). The completely lysed samples were then centrifuged. AL Buffer (Lysis buffer) was added into the mixture as much as $200 \mu \mathrm{L}$ and then vortexed for $15 \mathrm{~s}$. The mixture was then incubated in $70^{\circ} \mathrm{C}$ for $10 \mathrm{~min}$ and then centrifuged. As much as 200 $\mu \mathrm{L}$ of absolute ethanol was added and the mixture was vortexed again for $15 \mathrm{~min}$ followed by a centrifugation. The mixtures were transferred into mini spin columns placed on $2 \mathrm{~mL}$ tubes, centrifuged in $8000 \mathrm{rpm}$ for $1 \mathrm{~min}$. The mini spin columns were transferred to new $2 \mathrm{~mL}$ tube and then added AW2 buffer (washing buffer 2) and centrifuged in $14000 \mathrm{rpm}$ for $3 \mathrm{~min}$. Tubes with filtrates were discarded and mini spin columns were transferred to new $2 \mathrm{~mL}$ tubes and centrifuged in the max speed for $1 \mathrm{~min}$. The mini spin columns were then transferred into 
$1.5 \mathrm{~mL}$ micro-centrifuge tube and added by AE buffer (elution buffer). The mixtures were then incubated in room temperature and centrifuged in $8000 \mathrm{rpm}$ for 1 min. The DNA was stored at $-20{ }^{\circ} \mathrm{C}$ until being used as PCR templates (Qiagen, 2016).

\section{Oligonucleotide Primers}

A total of 3 pairs of primers were utilized in each PCR reaction. A pair of mitochondria cyt $b$ primers used in this work is tabulated in Table 1 that was described by Kocher et al. (1989). In this study, both pork (Sus scrofa domestica) and beef (Bos Taurus) had 359 bp fragment length. The sequences and target region from cytochrome $b$ gene are presented in Figure 1 and Table 2. This study also used Porcine-specific primer and bovine-specific primers that were described by (Cheng et al., 2003).

\section{PCR Amplification of The Mitochondria cyt $b$ Gene}

Amplification of the mitochondria $c y t b$ gene of beef, pork, and wild boar meats were performed in a final volume of $50 \mu \mathrm{L}$ containing $10 \mu \mathrm{L}$ of $5 \mathrm{X}$ MyTaq Red Reaction buffer (5 mM dNTPs, $15 \mathrm{mM} \mathrm{MgCl}$ ) (Bioline, Germany), $2 \mu \mathrm{L}$ of $10 \mu \mathrm{M}$ each primer (forward and reverse), $1 \mu \mathrm{L}$ of 5 units of MyTaq HS Red DNA polymerase (Bioline, Germany), $33 \mu \mathrm{L}$ of RNAse/DNAse free water, and $2 \mu \mathrm{L}$ of DNA template. PCR was carried out with a temperature program consisting of the initial denaturation at $95^{\circ} \mathrm{C}$ for $1 \mathrm{~min}$, followed by 35 cycles of denaturation at $95^{\circ} \mathrm{C}$ for $15 \mathrm{~s}$ (Jakaria \& Noor, 2015), annealing at $55^{\circ} \mathrm{C}$ for $45 \mathrm{~s}$, polymerization at $72^{\circ} \mathrm{C}$ for 10 $\mathrm{s}$, and final elongation at $72^{\circ} \mathrm{C}$ for $1 \mathrm{~min}$. The amplicons were analyzed by electrophoresis using $1.5 \%$ agarose gel in 1X Tris base Acetic Acid and EDTA (TAE) buffer at $100 \mathrm{~V}$ for $30 \mathrm{~min}$ and stained by ethidium bromide $0.5 \mu \mathrm{g} \mathrm{mL} \mathrm{m}^{-1}$. One $\mathrm{kb}$ of DNA ladder (Thermo Scientific,
USA) was used as a size reference. The gels were visualized using UV trans-illuminator.

\section{PCR Amplification Using Porcine-specific Primer and Bovine-specific Primer}

Amplifications of specific DNAs of beef, pork, and wild boar meats were performed in a final volume of

Table 1. Oligonucleotide primer of mitochondrial DNA (cyt b) and porcine-specific primer and bovine-specific primers with their sequences

\begin{tabular}{|c|c|c|c|}
\hline Primer & $\begin{array}{l}\text { Size of PCR } \\
\text { products }(b p)\end{array}$ & Sequence & Reference \\
\hline CYT b-1 & 359 & $\begin{array}{l}\text { 5'-CCA TCC AAC ATC } \\
\text { TCA GCA TGA TGA AA-3' }\end{array}$ & $\begin{array}{l}\text { Kocher et al. } \\
\text { (1989) }\end{array}$ \\
\hline CYT b-2 & & $\begin{array}{l}\text { 5'-CCC CTC AGA ATG } \\
\text { ATA TTT GTC CTC TCA-3' }\end{array}$ & \\
\hline POR F & 212 & $\begin{array}{l}\text { 5'-GCC TAA ATC TCC CCT } \\
\text { CAA TGG TA-3' }\end{array}$ & $\begin{array}{l}\text { Cheng et al. } \\
\text { (2003) }\end{array}$ \\
\hline POR R & & $\begin{array}{l}\text { 5'-ATG AAA GAA GCA } \\
\text { AAT AGA TTT TCG-3' }\end{array}$ & \\
\hline BOV F & 271 & $\begin{array}{l}\text { 5'-GCC ATA TAC TCT CCT } \\
\text { TGG TGA CA-3' }\end{array}$ & $\begin{array}{l}\text { Cheng et al. } \\
\text { (2003) }\end{array}$ \\
\hline BOV R & & $\begin{array}{l}\text { 5'-GTA GGC TTG GGA } \\
\text { ATA GTA CGA-3' }\end{array}$ & \\
\hline
\end{tabular}

Table 2. Restriction enzymes and the target region

\begin{tabular}{cc}
\hline Restriction enzymes & Target region \\
\hline AluI & $5^{\prime}$-AG CT-'3 \\
BsaJI & 5'-C CNNGG-'3 \\
HindIII & 5'-A AGCTT-'3 \\
RsaI & 3'-CA TG-'5 \\
HaeIII & 5'-GG CC-'3 \\
Taq $\alpha I$ & 3'-T CGA-'5 \\
\hline
\end{tabular}

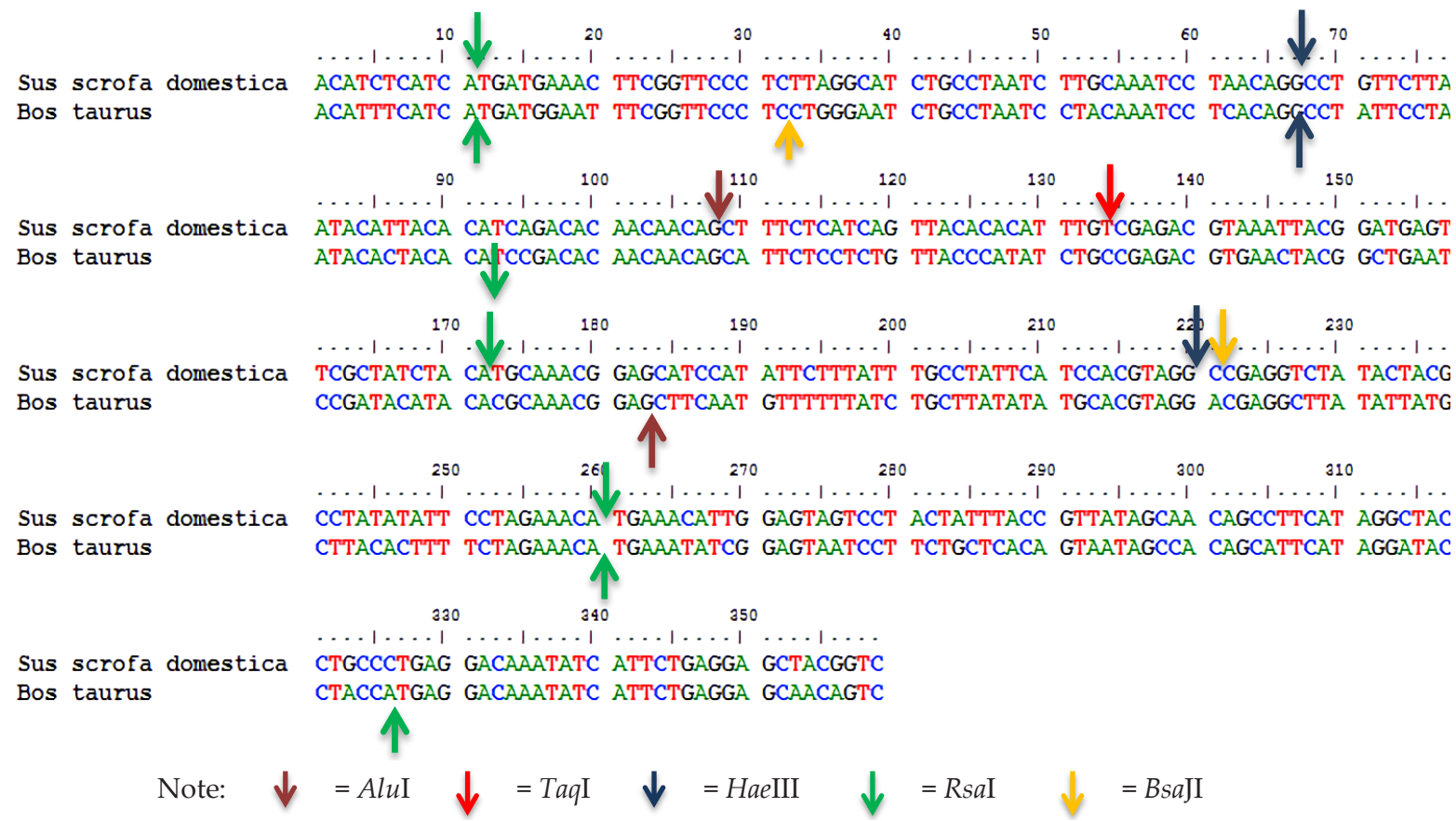

Figure 1. Target region of primer cytochrome $b$ gene 
$50 \mu \mathrm{L}$ containing $10 \mu \mathrm{L}$ of 5X MyTaq Red Reaction buffer (5mM dNTPs, $15 \mathrm{mM} \mathrm{MgCl}_{2}$ ) (Bioline, Germany), $2 \mu \mathrm{l}$ of $10 \mu \mathrm{M}$ each primer (forward and reverse), $1 \mu \mathrm{L}$ of 5 units of MyTaq HS Red DNA polymerase (Bioline, Germany), $33 \mu \mathrm{L}$ of RNAse/DNAse free water and $2 \mu \mathrm{L}$ of DNA template. PCR was carried out with a temperature program consisting of the initial denaturation at $95^{\circ} \mathrm{C}$ for $1 \mathrm{~min}$, followed by 35 cycles of denaturation at $95^{\circ} \mathrm{C}$ for $15 \mathrm{~s}$, annealing at $58^{\circ} \mathrm{C}$ for $1 \mathrm{~min}$, polymerization at $72^{\circ} \mathrm{C}$ for $10 \mathrm{~s}$ and final elongation at $72^{\circ} \mathrm{C}$ for 1 min. The amplicons were analyzed by electrophoresis using 1\% agarose gel in 1X Tris base Acetic Acid and EDTA (TAE) buffer at $100 \mathrm{~V}$ for $30 \mathrm{~min}$ and stained by ethidium bromide $0.5 \mu \mathrm{g} \mathrm{mL} \mathrm{mL}^{-1}$. One $\mathrm{kb}$ DNA ladder (Thermo Scientific, USA) was used as a size reference. The gels were visualized using UV trans-illuminator.

\section{Restriction Fragment Length Polymorphism (RFLP)}

PCR amplicons of the cyt $b$ gene were subjected to restriction enzyme digestion with restriction enzyme AluI, BsaJI, HindIII, RsaI, HaeIII, and Taq ${ }^{\alpha}$ according to the suppliers' instructions (Biolabs). Briefly, reaction mix was prepared by mixing $43 \mu \mathrm{L}$ of $\mathrm{ddH}_{2} \mathrm{O}, 5 \mu \mathrm{l}$ of buffer solution, $1 \mu \mathrm{L}$ of enzyme $(1 \mathrm{U} \mu \mathrm{L}-1)$, and $1 \mu \mathrm{L}$ of template DNA from PCR product and incubated at $37^{\circ} \mathrm{C}$ for $15 \mathrm{~min}$ for samples using AluI, RsaI, and HaeIII enzyme respectively, while samples utilizing HindIII were incubated for $60 \mathrm{~min}$. Incubation for digestion process by $\mathrm{BsaJI}$ was $60^{\circ} \mathrm{C}$ for $1 \mathrm{~h}$ while by Taq ${ }^{\alpha} \mathrm{I}$ enzyme was for $60^{\circ} \mathrm{C}$ for $1 \mathrm{~h}$. Inactivation was done at $80^{\circ} \mathrm{C}$ temperature for 20 min except those using RsaI enzyme, which were exempted from the process. Visualization of amplification was analyzed according to Amalianingsih et al. (2015) with minor modification on Agarose gel 3\% containing $2.5 \mu \mathrm{L}$ EtBr (ethidium bromide) and 0.5X TBE buffer (1 M Tris, 0.9 M Boric acid, 0.01 M EDTA pH 8.0) with a $100 \mathrm{bp}$ ladder (Invitrogen, USA) as a molecular weight marker for confirmation of the length of PCR product.

\section{RESULTS}

The PCR amplification analysis was conducted using cyt $b$ and species-specific primers on pork (Sus scrofa domestica), Sumateran wild boar meat (Sus scrofa vittatus), and beef (Bos taurus). The amplification products of each reaction were electrophoresed on $1.5 \%$ of agarose gel. Figure 2 shows the PCR amplification products of

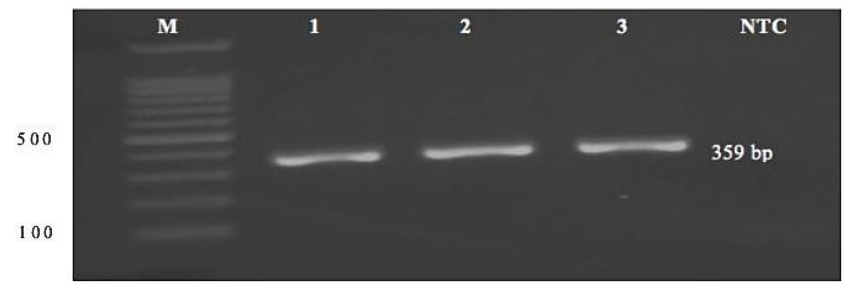

Figure 2. Agarose gel electrophoresis of amplification product of $c y t b$ gene. (M: $1 \mathrm{~kb}$ marker, 1: pork, 2: Sumateran wild boar meat, 3: beef, 4: NTC). pork, Sumateran wild boar meat, and beef by cyt $b$ primers. Using these primers, the amplification products of pork, Sumateran wild boar meat, and beef produced a single band with molecular size of $359 \mathrm{bp}$, respectively. Meanwhile, using the species-specific for porcine and bovine species primers, pork and Sumateran wild boar meats also produced a single band with molecular size of $212 \mathrm{bp}$ and $271 \mathrm{bp}$ for beef (Figure 3). No band was observed for non-template control (NTC) in each experiment.

The PCR amplification products using cyt $b$ primers were subsequently examined for PCR-RFLP analysis using six different restriction enzymes i.e., AluI, BsaJI, HindIII, RsaI, HaeIII, and Taq ${ }^{\alpha}$ I. Table 3 shows the band sizes of cyt $b$ PCR amplification products of pork, Sumateran wild boar meat, and beef when are digested by AluI, BsaJI, HindIII, RsaI, HaeIII, and Taq ${ }^{\alpha}$ I restriction enzymes.

Two bands were observed in all meats when PCR amplification product was digested with AluI restriction enzyme (Figure 4). The PCR-RFLP analysis of pork and Sumateran wild boar meat using AluI restriction enzyme produced bands with molecular size of $115 \mathrm{bp}$ and $244 \mathrm{bp}$, meanwhile, beef amplicon was digested and produced $169 \mathrm{bp}$ and $190 \mathrm{bp}$ (Figure 4).

Similarly, BsaJI restriction enzyme produced bands with molecular sizes of $228 \mathrm{bp}$ and $131 \mathrm{bp}$ for pork and wild boar, meanwhile, beef amplicon was digested and produced $320 \mathrm{bp}$ and $39 \mathrm{bp}$. Taq ${ }^{\alpha} \mathrm{I}$ restriction enzyme showed 2 bands with molecular sizes of $131 \mathrm{bp}$ and 228 bp for pork and Sumateran wild boar meats. However, it failed to digest beef DNA fragments in repeated experiments that produced a single band of $359 \mathrm{bp}$ in size.

However, using the HindIII enzyme was undigested all meats DNA. On the other hand, RsaI successfully digested all meats DNA and produced 320

Table 3. Restriction pattern of $c y t b$ gene for pig, Sumateran wild boar, and cattle

\begin{tabular}{lccc}
\hline $\begin{array}{l}\text { Species } \\
\text { enzymes }\end{array}$ & Pig & $\begin{array}{c}\text { Sumateran } \\
\text { wild boar }\end{array}$ & Cattle \\
\hline AluI & $244+115$ & $244+115$ & $190+169$ \\
BsaJI & $228+131$ & $228+131$ & $320+39$ \\
HindIII & - & - & - \\
RsaI & $320+39$ & $320+39$ & $320+39$ \\
HaeIII & - & $200+131+28$ & $285+74$ \\
Taq $\alpha I$ & $228+131$ & $228+131$ & - \\
\hline
\end{tabular}

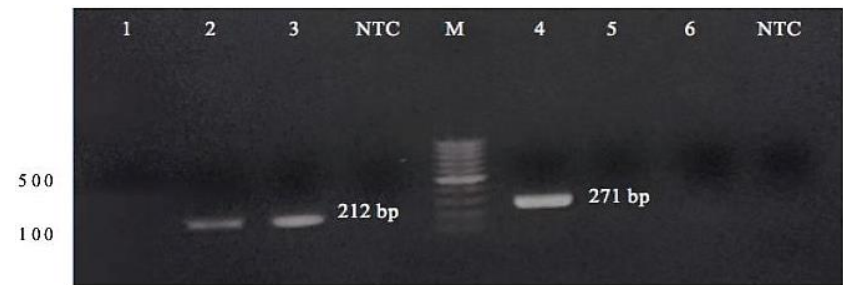

Figure 3. Polymerase chain reaction (PCR)-amplification of porcine specific and bovine specific gene. (M: $1 \mathrm{~kb}$ marker, 1: pork, 2: Sumateran wild boar meat, 3: beef, 4: pork, 5: Sumateran wild boar, 6: beef, 7: NTC). 
bp. Surprisingly, only HaeIII that successfully digested Sumateran wild boar amplicons into 3 fragments of 74 bp, $132 \mathrm{bp}$, and $153 \mathrm{bp}$ (Figure 5).

\section{DISCUSSION}

The method for species identification of meat products has increasingly turned towards DNA-based techniques in overcoming the limitations of existing methods (Rahmati et al., 2016). Genetic traceability is based on the identification of both animals and their products through the DNA analysis. The use of DNA techniques provides different levels of identification: (i) individual traceability to ensure food safety; and (ii) traceability of individuals to their source breeds or species to detect possible labeling adulterations (Nuraini et al., 2012).

Mitochondrial DNA (mt-DNA) is the genetic material that exists outside the nucleus in eukaryotic cells. It has a simple molecular structure. It does not undergo recombination with the nuclear DNA and has no identical sequence with the nuclear DNA. It has multiple copies and a rapid evolutionary rate and follows maternal inheritance. Cytochrome b gene (Cyt b) is one of the genes that are coded by mt-DNA and its gene product plays an important role in electron transfer in the respiration chain. Cytochrome b gene has a moderate evolutionary rate and a clear evolutionary pattern that makes it suitable for the studies on the phylogenetic evolution at the intra-and interspecific levels (Kunda et al., 2016). The mt DNA sequences have been widely used in evolutionary genetic studies because they are easily accessible, have a high rate of evolution and generally follow a clonal pattern of inheritance highly suited to phylogenetic reconstruction. The relatively high mutation rate compared to nuclear genes has tended to result in the accumulation of enough point mutations to allow the discrimination of closely related species (Kumar et al., 2013). The cyt $b$ sequences are good tools for studying more precise species identifications (Foran et al., 2015). Mitochondria cyt $b$ primer used in this study for differentiation of pork, Sumateran wild boar meet, and beef. In this study, the amplification product of pork, Sumateran wild boar meat, and beef produced a single band with a molecular size of $359 \mathrm{bp}$, respectively. The molecular size of cyt $b$ in this study agreed with previous study (Mutalib et al., 2012). Since cyt $b$ primer is universal primer, this primer

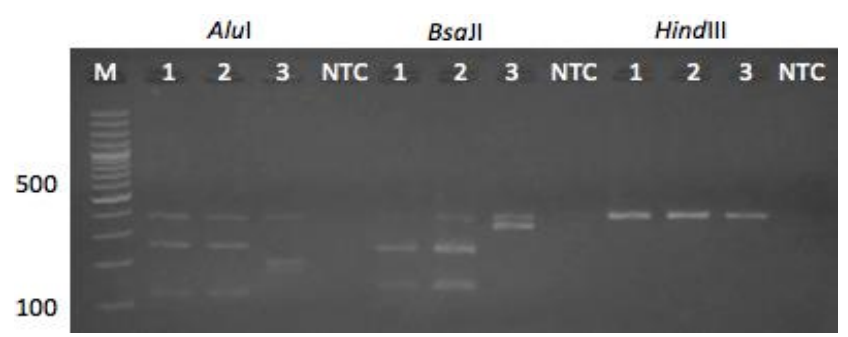

Figure 4. Restriction profiles of the cyt $b$ PCR products obtained from pig (1); Sumateran wild boar (2); and cattle (3), after digesting with $A l u \mathrm{I}, B s a \mathrm{JI}$ and HindIII. (M: DNA molecular weight marker $100 \mathrm{bp}$ ladder (Invitrogen), NTC: Non-template control. cannot distinct pork, Sumateran wild boar meat, and beef origin.

The species-specific primers for porcine and bovine were also studied. PCR using species-specific primers is one of the most used approaches since it offers simplicity, specificity, and high sensitivity for meat authentication studies (Amaral et al., 2014). The primers for every species would only amplify the DNA of that particular species (Man et al., 2007).

In this study, the species-specific primers used were successfully distinguished porcine meat (pork and Sumateran wild boar) and beef. According to Castello et al. (2004), bovine specific primers can be used to detect the presence of beef DNA within pig DNA up to $0.05 \%$ cattle sample concentration within $99.95 \%$ concentration of pig sample. On the other hand, amplification by pig specific primer can be used to directly detect pigderived materials in a foodstuff (Man et al., 2007). Also, this primer can detect pig-derived material up to $0.5 \%$ of concentration within foodstuff and possibly with even lower concentration (Ilhak \& Arslan, 2006). However, the porcine-specific primer cannot distinguish pork and Sumateran wild boar in this study.

Cyt $b$ has been used by various researches to identify meat types (Erwanto et $a l ., 2012)$. Cyt $b$ gene has been used in various studies that identify the presence of DNA originating from pig or beef in food products or foodstuff and identifying various species, especially in studies utilizing PCR-RFLP (Verkaar et al., 2002; Aida et al., 2005; Murugiah et al., 2009; Mutalib et al., 2012; Erwanto et al., 2011; Erwanto et al., 2012). Doosti et al. (2014) investigated the PCR-RFLP analysis of the mitochondrial $c y t b$ gene to differentiate between beef, sheep, pork, chicken, donkey, and horse meat in meat products (sausages, frankfurters, hamburgers, hams, and cold cut meats) and suggested that this method provided a potential technique to rely on for authentication of halal (law or permitted) meat origin.

Important advantages of the PCR-RFLP technique include inexpensiveness and lack of requirement for advanced instruments. In addition, the design of PCRRFLP analyses is generally easy and can be accomplished using public available programs (Rasmussen, 2012). The proposed Cytb-PCR-RFLP assay represents a fast and delicate technique appropriate to the detection and authentication of poultry meat species (Razzaq et al., 2017).

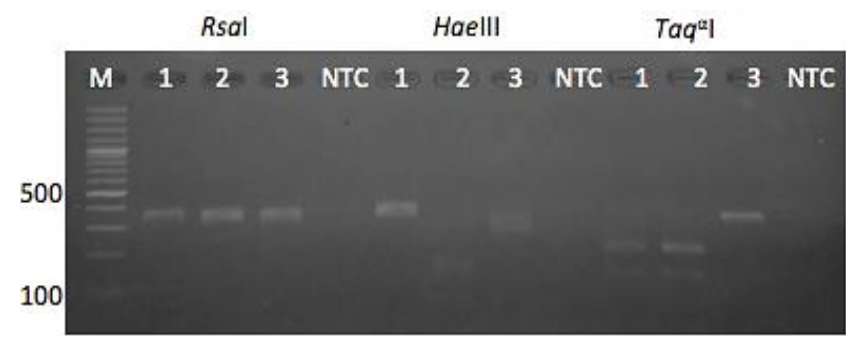

Figure 5. Restriction profiles of the cyt $b$ PCR products obtained from pig (1); Sumateran wild boar (2); and cattle (3), after digesting with RsaI, HaeIII and Taq ${ }^{\alpha}$ I. (M: DNA molecular weight marker $100 \mathrm{bp}$ ladder (Invitrogen), NTC: Non-template control. 
PCR-RFLP (PCR restriction fragment length polymorphism) is a stable, rapid, and inexpensive technique that combines PCR and restriction endonuclease digestion and has received many attentions in identifying genetic diversity and developing biomarkers for the authentication of adulterants at the species level. Additionally, this technique can semi-quantitatively detect contamination in authentic samples and can be performed quickly and inexpensively. Another advantage of PCR-RFLP is an accurate and authentic PCR-based authentication method based on (1) using universal primers to amplify a conserved region, (2) digesting the PCR product with specific restriction endonucleases, and (3) separating the digest fragments by agarose gel electrophoresis (Jiang et al., 2018).

Dubey et al. (2010) stated on their study that they chose restriction fragment length polymorphism (RFLP) technique, because it was less time-consuming, more cost-effective than DNA sequencing, the equipment was available in most molecular laboratories, and it was proved its utility in species identification.

Another study conducted by Meganathan et al. (2009) stated that a simpler alternative to the DNA sequencing technique was restriction fragment length polymorphism analysis of PCR products (PCRRFLP). This technique proved to be a simple, rapid, and costeffective method for species identification and had been used in forensic examination to authenticate the confiscated biological materials.

In this study, using the cyt $b$ gene, pork, Sumateran wild boar meat, and beef produced amplified fragment of $359 \mathrm{bp}$ in size (Figure 1). Furthermore, the PCR-RFLP analysis was conducted and the RFLP profiles of all of meats were differentiated by two different restriction enzymes of $A l u \mathrm{I}$. However, this enzyme is not able to distinguish pork and Sumateran wild boar meat since they have the same size of $115 \mathrm{bp}$ and $244 \mathrm{bp}$ for each fragment. Surprisingly, previous study (Mutalib et al., 2012) did not find any fragment in wild boar meat using AluI enzyme.

Based on study using the other enzymes, BsaJI digestion generated $115 \mathrm{bp}$ and $244 \mathrm{bp}$ for pork and Sumateran wild boar meat while it produced $320 \mathrm{bp}$ for beef. The fragment size produced by BsaJI in this study is in agreement with previous study (Murugiah et al., 2009). It indicates that BsaJI can be used as a restriction endonuclease to differentiate porcine meat and beef. However, it is not adequate to distinct pork and Sumateran wild boar meat. In this study, we also compared with other restriction endonuclease i.e., $\operatorname{Taq}^{\alpha} \mathrm{I}$. We found that $c y t b$ gene digestions originating from pork and Sumateran wild boar meats performed with these enzymes resulted in two DNA fragments (228 to 131 $\mathrm{bp}$ ). However, these enzymes failed to digest beef after repeated experiments. To the best of our knowledge, this is the first study on $\operatorname{Taq}^{\alpha} \mathrm{I}$ as restriction enzyme in meat authentication. $\mathrm{Ta}^{\alpha} \mathrm{I}$ is not appropriate for differentiation of neither the closely related species pork and Sumateran wild boar nor beef digestion. On the other hand, HindIII enzymes did not cleave the PCR products of any of the tested meat, while $R s a$ I restriction enzyme produced $320 \mathrm{bp}$ for all of meats. These results are similar to the previous work (Murugiah et al., 2009).

Finally, the HaeIII cleavage bands visualized in the gel were enough and suitable for the discrimination of all species analyzed. In this study, it was observed that HaeIII was the only specific enzyme to differentiate between pork, Sumateran wild boar, and beef meat.

PCR-RFLP analysis of the cyt $b$ gene provides a simple, relatively quick, and accurate identification of Sumateran wild boar species. In this study, PCR RFLP analysis only required 4 hours. Jiang et al. (2018) in their study also state that in general, a common PCR RFLP analysis requires $4-5 \mathrm{~h}$, limiting its application in a routine species identification studies.

\section{CONCLUSION}

The species-specific primers used were successfully distinguished porcine meat (pork and Sumateran wild boar) and beef. Among six tested enzymes, the use of PCR-RFLP analysis of the cyt $b$ gene followed by digestion using HaeIII restriction enzyme provides a simple, relatively quick, and accurate identification of Sumateran wild boar species. This method could be used to identify Sumateran wild boar meat falsified as beef which is typically common practice in Indonesia.

\section{CONFLICT OF INTEREST}

There is no conflict of interest with any financial, personal, or other relationship with other people or organization related to the material discussed in the manuscript.

\section{ACKNOWLEDGEMENT}

The authors would like to give a thank you remark to Indonesian Agricultural Quarantine Agency (IAQA) that provided financial support for present study. We also would like to give thank you for DR. Ni Luh Putu Ika Mayasari for useful suggestion to improve this study and manuscript.

\section{REFERENCES}

Aida, A. A., Y. B. C Man, C. M. V. L.Wong, A. R. Raha, \& R. Son. 2005. Analysis of raw meats and fats of pigs using polymerase chain reaction for Halal authentication. Meat Sci. 69:47-52. https://doi.org/10.1016/j.meatsci.2004.06.020

Alikord, M., H. Momtaz, M. Kadivar, \& A. H. Rad. 2018. Species identification and animal authentication in meat products: a review. Food Measure.12:145-155. https://doi. org/10.1007/s11694-017-9625-z

Amalianingsih, T. I., B. Brahmantiyo, \& Jakaria. 2015. Identification of rabbit myostatin gene polymorphism. Med. Pet. 38:78-81. https://doi.org/10.5398/ medpet.2015.38.2.77

Amaral, J. S., C. G. Santos, V. S. Melo, M. B. P. Oliveira, \& I. Mafra. 2014. Authentication of a traditional game meat sausage (Alheira) by species-specific PCR assays to detect hare, rabbit, red deer, pork and cow meats. Food Rest. Int. 60:140-145. https://doi.org/10.1016/j.foodres.2013.11.003

[Bkpcilegon] Agricultural Quarantine Office Class II Cilegon. 
2015. Annual Report 2014. Cilegon (ID); Republic of Indonesia.

Castello, A., O. Francino, B. Cabrera, J. Polo, \& A. Sanchez. 2004. Identification of bovine material in porcine spraydried blood derivatives using the Polymerase Chain Reaction technique. Biotechnol. Agron. Soc. Environ. 8:267-273.

Cheng, Y., H., C. M. Wen, S. T. Ding, C. C. Kao, \& T. Y. Kuo. 2003. Detecting meat-and-bone meal in ruminant's feeds by species-specific PCR. J Anim. Feeds Sci. 12:851-860. https://doi.org/10.22358/jafs/67779/2003

Doosti, A., D. P. Ghasemi, \& E. Rahimi. 2014. Molecular assay to fraud identification of meat products. J. Food Sci. Technol. 51:148-152. https://doi.org/10.1007/s13197-011-0456-3

Dubey, B., P. R. Meganathan, \& I. Haque. 2010. Molecular identification of three Indian Snake species using simple PCR-RFLP method. Forensic Sci. 4: 1065-1067. https://doi. org/10.1111/j.1556-4029.2010.01384.x

Erwanto, Y., M. Z. Abidin, A. Rohman, \& Sismindari. 2011. PCR-RFLP using BseDI enzyme for pork authentication in sausage and nugget products. Med. Pet. 31:14-18. http:// dx.doi.org/10.5398/medpet.2011.34.1.14

Erwanto, Y., Sugiyono, A. Rohman, M. Z. Abidin, \& D. Ariyani. 2012. Pork identification using PCR-RFLP of $c y$ tochrome $b$ gene and species specific PCR of amelogenin gene. Agritech. 32: 370-377.

Fajardo, V., I. Gonzales, M. Rojas, P. E. Hernandez, T. Garcia, \& R. Martin. 2007. Differentiation of European wild boar (Sus scrofa scrofa) and domestic swine (Sus scrofa domestica) meats by PCR analysis targeting the mitochondrial D-loop and the nuclear melanocortin receptor 1 (MC1R). Meat Sci. 78:314-322. https://doi.org/10.1016/j.meatsci.2007.06.018

Farag, M. R., M. Alagawany, M. E. A. El-Hack, R. Tiwari, \& K. Dhama. 2015. Identification of different animal species in meat and meat products: trends and advances. J AAVS. 3:334-346.

Foran, D. R., A. B. Fischer, \& M. E. Stoloff. 2015. A comparison of mitochondrial DNA amplification strategies for species identification. J. Forensic Investigation. 3:7.

Haider, N., I. Nabulsi, \& B. Al-Safadi. 2012. Identification of meat species by PCR-RFLP of the mitochondrial COI gene. Meat Sci. 90: 490-493. https://doi.org/10.1016/j. meatsci.2011.09.013

Ickes, K. 2001. Hyper-abundance of native wild pigs (Sus scrofa) in a lowland dipterocarp rain forest of Peninsular Malaysia. Biotropica. 33:682-690. https://doi. org/10.1111/j.1744-7429.2001.tb00225.x

Ilhak, O. I., \& A. Arslan. 2007. Identification of meat species by polymerase chain reaction (PCR) technique. J. Vet. Anim. Sci. 31:159-163.

Irene, H. Nuraini, \& C. Sumantri. 2013. Species authentication of dog, cat, and tiger using cytochrome $\beta$ gene. Med. Pet. 36: 171-178. http://dx.doi.org/10.5398/medpet.2013.36.3.171

Jakaria \& R. R. Noor. 2015. Identification of a single nucleotide polymorphism at Hinf1 enzyme restriction site of Pit1 gene on Indonesian Bali Cattle Population. Med Pet. 38: 104-109. http://doi.org/10.5398/medpet.2015.38.2.104

Jiang, C., Y. Jin, X. Zhao, Y. Yuan, Y. Zhao, \& L. Huang. 2018. Rapid and robust authentication of deer antler velvet product by fast PCR-RFLP. Mitochondrial DNA Part A 29: 266-272. https://doi.org/10.1080/24701394.2016.1275599

Karabanasavar, N. S., S. P. Singh, V. Umapathi, D. Kumar, \& S. N. Shebanavar. 2011. Identification of goat meat using highly species-specific polymerase chain reaction. J. Food Qual. 34:142-149. https://doi. org/10.1111/j.1745-4557.2011.00376.x

Kocher, T. D., W. K. Thomas, A. Meyer, S. V. Edwards, S. Paabo, F. X. Villablanca, \& A. C. Wilson. 1989. Dynamics of mitochondrial DNA evolution in animals: Amplification and sequencing with conserved primers. Proc. Natt. Acad. Sci. 86:6196-6200. https://doi.org/10.1073/pnas.86.16.6196

Kumar, A., R. R. Kumar, B. D. Sharma, P. Gokulakrishnan, S. K. Mendiratta, \& D. Sharma. 2015. Identification of species origin of meat and meat products on the DNA basis: a review. Critical reviews in food science and nutrition. 55:1340-1351. https://doi.org/10.1080/10408398.2012.69397 8

Kunda, R. M., N. S. N. Handayani, H. Wijayanto, \& R. Widayanti. 2016. Study of genetic marker of Cuscuses (Marsupialia: Phalangerida) from Maluku and Papua based on Cytochrome b gene sequence. Pak. J. Biol. Sci. 19: 122-135. https://doi.org/10.3923/pjbs.2016.122.135

Lenstra, J. A., J. B. Buntjer, \& F. W. Janssen. 2001. On the origin of meat-DNA techniques for species identification in meat products. Vet. Sci. 1-15.

Luskin, M. S., E. D. Christina, L. C. Kelley, \& M. D. Potts. 2014. Modern hunting practices and wild meat trade in the oil palm plantation-dominated landscapes of Sumatra, Indonesia. Human Ecology. 42:35-45. https://doi. org/10.1007/s10745-013-9606-8

Man, Y. B. C., A. A. Aida, A. R. Raha, \& R. Son. 2007. Identification of pork derivates in food products by species-specific polymerase chain reaction (PCR) for halal verification. J. Food Cont. 18:885-889. https://doi.org/10.1016/j. foodcont.2006.05.004

Meganathan, P. R., B. Dubey, \& I. Haque. 2009. Molecular identification of Indian Crocodile species: PCR-RFLP method for forensic authentication. Forensic Sci. 5: 10421045. https://doi.org/10.1111/j.1556-4029.2009.01119.x

Minarovic, T., A. Trakovicka, A. Rafayova, \& Z. Lieskovska. 2010. Animal species identification by PCR-RFLP of cytochrome b. Scientific Paper. Anim. Sci. Biotechnol. 43:296-299.

Murugaiah, C., Z. M. Noor, M. Mastakim, L. M. Bilung, J. Selamat, \& S. Radu. 2009. Meat species identification and Halal authentication analysis using mitochondrial DNA. Meat Sci. 83:57-61. https://doi.org/10.1016/j. meatsci.2009.03.015

Mutalib, S. A., W. S. W. Nazri, S. Shahimi, N. Yaakob, N. A. Sani, A. Abdullah, A. S. Babji, \& M. A. Ghani. 2012. Comparison between pork and wild boar meat (Sus scrofa) by polymerase chain reaction-restriction fragment length polymorphism (PCR-RFLP). JSM. 41:199-204.

Nuraini, H., A. Primasari, E. Andreas, \& C. Sumantri. 2012. The use of cytochrome $\mathrm{b}$ gene as a specific marker of the rat meat products. Med. Pet. 35: 15-20. http://dx.doi.org/10.5398/ medpet.2012.35.1.15

Oceja, L. A., C. Nunez, M. Baeta, D. Gamarra, \& M. M. de Pancorbo. 2017. Species identification in meat products: A new screening method based on high resolution melting analysis of $c y t b$ gene. J. Food Chem. 237:701-706. https:// doi.org/10.1016/j.foodchem.2017.06.004

Pascoal, A., M. Prado, J. Castro, A. Cepeda, \& J. BarrosVelazquez. 2004. Survey of authenticity of meat species in food products subjected to different technology processes, by means of PCR-RFLP analysis. Eur. Food Res. Technol. 218:306-312. https://doi.org/10.1007/s00217-003-0846-5

Rahmati, S., N. M. Julkapli, W. A. Yehye, \& W. J. Basirun. 2016. Identification of meat origin in food products-A review. Food Control. 68:379-390. https://doi.org/10.1016/j. foodcont.2016.04.013

Qiagen. 2016. QIAMP®DNA mini handbook: for DNA purification from whole blood, plasma, serum, buffy coat, lymphocytes, dried blood spots, (QIAMP DNA Mini Kit Only), body fluid, cultured cells, swabs and tissue (QIAMP DNA Mini Kit Only).

Rassmusen, H. B. 2012. Restriction Fragment Length Polymorphism Analysis of PCR Amplified Fragments 
(PCR-RFLP) and Gel Electrophoresis-Valuable Tool for Genotyping and Genetic Fingerprinting. InTech Publisher. Denmark.

Razzaq, A., A. Nawaz, N. Saeed, A. Hayee, \& A. Ali. 2017. Modern preventive techniques of meat adulteration for improving public health. J Biosci. 4:127-131.

Spychaj, A., M. Szalata, R. Slomski, \& E. Pospich. 2016. Identification of bovine, pig and duck species in mixture and in meat products on the basis of mtDNA Cytochrome Oxidase Subunit I (COI) gene sequence. Pol. J. Nutr. Sci. 66:31-36.

Verkaar, E. L. C., I. J. Nijman, K. Boutaga, \& J. A. Lenstra. 2002. Differentiation of cattle species in beef by PCR-RFLP of mitochondrial and satellite DNA. Meat Sci. 60:365-369. https://doi.org/10.1016/S0309-1740(01)00144-9 